\section{Snakes of the United States and Canada}

By Carl H. Ernst and Evelyn M. Ernst. 2003. Smithsonian Books, Washington. $x i+668$ pages. US $\$ 70$, CAN $\$ 105.00$ ISBN 1-58834-019-8

It is over four-and-a-half decades since the publication of the comprehensive two-volume Handbook of Snakes of United States and Canada by Albert Hazen and Anna Allen Wright (reviewed in The Canadian Field-Naturalist 71(4): 201-202 by J. S. Bleakney, 1957). Those volumes emphasized the need for life history data and presented the first distribution maps for all species covered (this was a year before the first field guide to amphibians and reptiles in the Peterson series appeared). The intervening period has seen not only a proliferation of ecological and behavioural studies but the compilations of extensive data-bases on distribution for virtually every region of North America. In the new treatment of North American snakes, the Ernsts have synthesized much of the new information and integrated it with the historic data in detailed species accounts.

A seven-page Introduction begins with remarks on the taxonomic position snakes (over 2600 are recognized in the world) as a suborder (Serpentes) of the order Squamata which they share with lizards. Following are capsule sections on origins (the oldest fossil snake is from the early Cretaceous Period). The modern snake fauna (6 families, 52 genera and 131 species occur in North America), characteristics, habitat, activity periods, movements, reproduction, diet, predators and defense, venoms, populations, conservation. Two pages on identification include labelled diagrams of scale patterns and a key to the families.

The family and species accounts occupy 554 pages: Leptotyphlopidae (Slender Blindsnakes) 1 genus, 2 species; Typhlopidae (Blindsnakes) 1, 1 (introduced); Boidae (Boas) 2, 3 (one of these introduced); Colubridae (Colubrid Snakes - both harmless and rearfanged species) 42, 105; Elapidae (Elapid Snakes coral snakes and the marine Yellow-bellied Sea Snake) 3, 3; Viperidae (Viperid Snakes - represented by the subfamily Crotalinae, the pit vipers) 3,17 . Each account has sections on Recognition, Geographic Variations (including definition of all subspecies, some recognized as full species by other authors, and reference to forms once named but not currently recognized), Confusing Species, Karyotype, Fossil Record, Distribution (both as text and as a black patch on outline map of U.S. states, and, for the 25 species which range north of the U.S., the relevant portions of Canadian provinces), habitat, behavior, reproduction, growth and longevity, diet and feeding habits, predators and defense, populations (abundance), and remarks (additional aspects). Throughout the accounts sharp colour photographs illustrate each species and some distinctive subspecies.
The maps have surprisingly good detail despite their size which ruled out plotting individual records. The subdivisions of ranges into subspecies is not mapped but given only in the text. Distributions for the 25 species (three families) which range into Canada are generally accurate. Exceptions may be the central Saskatchewan, Alberta and British Columbia portions for the Western Terrestrial Gartersnake Thamnophis elegans (page 385) and the central Alberta and British Columbia portions for Thamnophis sirtalis (page 429) where, following some other recent authors, a disjunct patchwork is shown. These likely reflect just a lack of sufficient observations in these areas rather than actual range gaps. There is a northernmost disjunct shown for the Northwestern Garter Snake, Thamnophis ordinoides (page 403), apparently in the vicinity of Bella Coola. However, specimens identified as to this species in the literature are actually Thamnophis elegans vagrans (Canadian Museum of Nature, FRC unpublished data). A lapsus in paste-up has caused the map for the Common Garter Snake, Thamnophis sirtalis (page 429), to lose the portion for northern Alberta into the Northwest Territories at Fort Smith. This is unfortunate as it includes the most northerly record for a reptile in North America, documented as early as the beginning of the 20th century. However, this part of the range is included in the text. A discredited record for the Sharp-tailed Snake Contia tenuis (page 88) for the British Columbia interior continues to be plotted here. The northern limit of the Brown Snake Storeria dekayi is probably too generous in Quebec but the stylized boundaries of the map in this area make this hard to evaluate.

Some taxonomic details will be of interest to Canadian workers. The generic name Liochlorophis is accepted for the Smooth Green Snake (L. vernalis) but three previously named subspecies (vernalis, blanchardi, and borealis) are not. For the Plains Garter Snake (Thamnophis radix) the subspecies haydeni is no longer recognized. However, the subspecific status of the Blue Racer Coluber constrictor foxii for Great Lakes populations is considered valid, as are the two subspecies of Brown Snake (Storeria dekayi) that intergrade in Ontario and Quebec (dekayi $\times$ wrightorum). The Black Hills Red-bellied Snake (Storeria occipitomaculata pahasapae) is now regarded as intergrading with $S$. o. occipitomaculata in "southern Canada" [= Saskatchewan, Manitoba and northwestern Ontario]. The Gopher Snakes and Bullsnake are grouped as Pituophis catenifer now separate from the southeastern Pine Snakes (P. melanoleucus). Differing from some recent authors, The Western Yellow-bellied Racer Coluber constrictor mormon, the Fox Snake Elaphe vulpina gloydi and the Northern Pacific Rattlesnake Crotalus viridis oreganus are not elevated to species status. The text was apparently completed prior to publication of a revision of the Ratsnake Elaphe 
obsoleta and the consequent elevation of E. o. spiloides to a species (as Elaphe Spiloides) which now includes all Ontario populations (Burbink et al. 2000; Burbink 2001).

The book concludes with a four-page Glossary presenting an English translation for genus, species, and subspecific names, and an 102-page Bibliography. I did not note any more recent than the year 2000. Citations in the species accounts reference sources for most but the more general statements allowing them to be verified and/or searched for additional information.

Its through synthesis of the literature will make this

\section{BOTANY}

\section{The Illustrated Encyclopedia of Trees}

By David More and John White. 2002. Timber Press, Inc., 133 S.W. Second Avenue, Suite 450, Portland, Oregon 97204-3527, USA www.timberpress.com; hardcover, 800 pages. U.S. $\$ 79.95$.

This is an absolutely beautiful book. Usually with one and a half pages per species are presented: painted illustrations of trees, flowers, fruits and leaves, often at different stages in spring, summer, fall and winter "found in Britain, France, Germany and the Low Countries - common or rare, native or introduced, growing wild or cultivated in arboreta, parks and gardens", by artist David More.

The accompanying text written by John White describes the native range of each species, approximate time of its introduction into cultivation, where it came from, the preferable habitat, various cultivars and various additional interesting information.

All of this is in family sequence beginning with the Ginkgo family and ending with the Palm family. Over 1000 species are treated. a standard reference for years to come for both researchers and naturalists with any interest in snakes.

\section{Literature Cited}

Burbink, E. T. 2001. Systematics of the eastern rat snake complex (Elaphe obsoleta). Herpetological Monographs 15: 1-53.

Burbink, E. T., R. Lawson, and J. B. Slowinski. 2000. Mitochondrial DNA phylogeography of the polytypic North American rat snake (Elaphe obsoleta): a critique of the subspecies concept. Evolution 54(6): 2107-2118

FRANCIS R. COOK

Canadian Museum of Nature, Ottawa, Ontario K1P 6P4 Canada
The book begins with a Table of Contents of two pages, two pages of Foreword and an Introduction of eleven pages with descriptive information including a list of trees for problem sites or special needs. It is completed by a Glossary, an Index of Scientific Names and an Index of Common Names. Its weight is about six pounds and for that reason should be best either kept at home or in an office and not carried into a garden or arboretum.

One thing that was not mentioned in the text is the possibility of a cultivated tree species invading into open or non-cultivated areas. Three species that have spread extensively in some areas in the vicinity of Toronto are Scots Pine (Pinus sylvestris), Silver Birch (Betula pendula) and Norway Maple (Acer platanoides).

WiLLIAM J. CODY

Biodiversity, National Program on Environmental Health, Agriculture and Agri-Food Canada, Wm. Saunders Building (49), Central Experimental Farm, Ottawa, Ontario K1A 0C6 Canada

\section{Carnivorous Plants of the United States and Canada: Second Edition}

By Donald E. Schnell. 2002. Timber Press, Inc. Portland, Oregon. 468 pages. U.S. \$39.95.

This book contains a wealth of information and absolutely beautiful colour pictures of 55 carnivorous plants which occur in the United States and Canada, some as far north as the Northwest Territories, Yukon and Alaska. It is a tremendous step ahead of the author's first edition which was published by John F. Blair in 1976 and numbered 125 pages.

In the new edition, there is a short three-page Preface in which the author calls attention to the changes, developments and explanations in the following text, the elimination of the cultivation chapter, comments about the photographs and thanks to many unnamed individuals and especially to his wife, Brenda.
The next 68 pages are devoted to Carnivorous Plants: An Introduction under the following headings: Carnivorous or Insectivorous, General Characteristics Related to Habitat, Must Carnivorous Plants be Carnivorous? Trapping Mechanisms, How Traps Attract Prey, Carnivorous Plant Communities, Carnivorous Plant Habitats, and Some General Notes on Cultivating Carnivorous Plants. All of these sections contain interesting information.

This is followed by the chapters Venus Flytrap, Eastern North American Pitcher Plants, California Pitcher Plant, Sundews, Butterworts, Bladderworts and Other Possible Carnivorous Seed Plants. Within each of these chapters is easy to read information on the families, genera and species, scientific names, and common names, descriptions, flowering seasons, dis- 